\section{EMBRYRIDDLE}

Aeronautical University

SCHOLARLY COMMONS
Journal of Aviation/Aerospace

Education \& Research

Volume 18

Number 2 JAAER Winter 2009

Article 5

Winter 2009

\title{
Implications of Current Federal Aviation Regulatory Policies \\ Governing Low Time Commercial Pilots who Transition to Single \\ Pilot/IFR Environments
}

Jeffrey A. Johnson

Steven L. Anderson

Tara L. Harl

Follow this and additional works at: https://commons.erau.edu/jaaer

\section{Scholarly Commons Citation}

Johnson, J. A., Anderson, S. L., \& Harl, T. L. (2009). Implications of Current Federal Aviation Regulatory Policies Governing Low Time Commercial Pilots who Transition to Single Pilot/IFR Environments. Journal of Aviation/Aerospace Education \& Research, 18(2). https://doi.org/10.15394/jaaer.2009.1422

This Article is brought to you for free and open access by the Journals at Scholarly Commons. It has been accepted for inclusion in Journal of Aviation/Aerospace Education \& Research by an authorized administrator of Scholarly Commons. For more information, please contact commons@erau.edu. 


\title{
IMPLICATIONS OF CURRENT FEDERAL AVIATION REGULATORY POLICIES GOVERNING LOW TIME COMMERCLAL PILOTS WHO TRANSITION TO SINGLE PILOT/IFR ENVIRONMENTS
}

\author{
Jeffrey A. Johnson, Steven L. Anderson, and Tara L. Harl
}

\begin{abstract}
The purpose of this study was to investigate the need to change FAA policy governing commercial pilot training and experience by soliciting the expertise from chief pilots and directors of flight operations who were members of the National Air Transportation Association (NATA). A descriptive survey questionnaire was specifically developed for this study to investigate attitudes and beliefs about the adequacy of a commercial pilot new hire's previous flight experience. The study found that a substantial number of aviation professionals believe that a new hire's previous pilot-in-command (PIC) experience in a single-pilot environment is inadequate. Major concerns include inadequate previous experience as PIC in a single pilot environment flying high performance multi-engine aircraft, inadequate instrument meteorological conditions (IMC) experience, substandard IMC experience at night, inadequate mountainous experience, and inadequate flight experience in hazardous conditions (icing conditions, slippery runways, etc.). Quality of flight time and experience were addressed as it related to commercial pilots. Recommendations were made to change existing FAA policies for new hire commercial pilots who transition to single pilot, multi-engine charter operations without any prior experience.
\end{abstract}

\section{Introduction}

Pilot training has tremendously evolved in complexity since the dawn of the $20^{\text {th }}$ century. With the advent of technologically sophisticated aircraft incorporating electronic flight instrumentation system (EFIS) and flight management systems (FMS), flight decks have been transformed into highly automated environments (Billings, as cited in Jacobson \& Mosier, 2005). Modern day automation is not only prolific in the flight decks of major airlines and corporate aircraft, but regional carriers as well. As flight deck sophistication has increased, so have the demands on pilot training. Regional airlines have recognized that the most important skill in modern day pilots is the ability to work well with flight crew members, other employees, and passengers-not simply an abundance of logged flight time (Regional Airline World, 2005).

Historically, pilots trained in the civilian world typically obtain a flight instructor certificate to build additional flight time and experience in preparation for transitioning to the right seat of a regional airliner or obtaining a charter pilot position. Although a newly certificated flight instructor can gain a substantial amount of flight experience in an instructional setting, the flight instructor can still remain very inexperienced as a commercial pilot with respect to making an initial transition to high performance aircraft (regional jet or a Beech Baron). Why? Most flight instructors spend a vast majority of their time instructing in low performance aircraft during daylight hours and in good weather. Ralph Hood (2005), an aviation speaker and writer, profoundly stated, "A Skyhawk is a fine airplane, but not exactly what you want to take into icing conditions and mountains" (p. 80). Even multi-engine instructors often instruct in non-high performance aircraft like the Beech Duchess or Piper Seminole in predominantly day VMC conditions. Flying a high performance aircraft at night, during inclement weather while in congested airspace over hostile terrain, demands a current set of specialized piloting skills that can challenge even the most seasoned 
veteran pilot. Some airports like Aspen, Colorado, can present an extremely hostile environment to even the most experienced pilot combining deteriorating weather, high mountainous terrain, with a complicated arrival. According to Landsberg (2005), 15 accidents have occurred in Aspen with four fatalities over the past decade. Unfortunately, advanced flight operational experiences at Aspen like airports are not routinely encountered until the flight instructor is employed by a regional or charter operator.

Experiencing certain circumstances or events in the real world will provide pilots with a better understanding (Namowitz, 2005) that could never be replicated in a classroom or flight instructional setting. Hence, regional airlines and charter operators look for experience although Schiff (1987) and Campbell (1987) have argued that defining experience in the context of aviation has been historically vague and certainly without universal agreement. For example, would a Prescott, Arizona based flight instructor with 5,000 hours total time and 4,700 hours instructing in Cessna 152s have more experience than a Buffalo, New York based charter pilot with 2,500 hours total time and 1,000 hours in a twin-engine Beech Baron certified for IFR operations in known icing? In part, the answer will not only depend on how experience is formally defined as suggested by Schiff (1987) and Campbell (1987) but also how quality of flight time is defined as well. In a research study conducted by Gill (2004), a lack of flying experience was cited as one reason why some employees violate safety.

This paper will address the following research question through the use of data responses: Is there a need to change FAA policy governing commercial pilot training and experience for low time pilots transitioning to single pilot/IFR environments? The lack of any formalized research studies suggests that the need to change FAA policy remains unclear although the results of this study seem to convey a substantive answer from aviation experts. The study does not attempt to address the philosophical question of safety: Is it safe for inexperienced commercial pilots transitioning to a multi-engine reciprocating airplane in a single pilot on demand charter environment? It should also be noted the researchers did not address the current automated flight deck technologies and the effect on inexperienced commercial pilots.

\section{Review of the Literature}

The aviation literature ranging from human factors, flight deck automation, to pilot training is profound and expansive. In the last two decades alone, advancements in flight deck modernization and automation seem to defy imagination. Despite these advances, some researchers (see Acheson \& Bowen, 1998) found that initial pilot training methodology and sequence has seen very little change in 60 years. Other studies (see Lutte \& Bowen, 2000) have suggested the FAA reacts to change after catastrophic airline accidents occur while others (Phillips, 1996) believe the FAA consistently refuses to acknowledge shortcomings. Some researchers have suggested that a need exists (and the aviation industry has been long overdue) for a new training model to improve decision making particularly in an IFR environment. Although the pilot training model (from a regulatory perspective) seems to have changed very little, there have been some innovative developments recently. In 2004, students were taught in a specialized program using an FAA approved scenario based syllabus known as FITS (FAA Industry Training Standards) resulting in a combined Private Pilot and Instrument Rating practical test (Craig, Bertrand, Dornan, Gossett \& Thorsby, 2005).

Unfortunately, the researchers in this study identified a critical area in aviation directly related to pilot training that seems to have changed little-FAA policy governing commercial pilot training and experience (readiness) for new hire commercial pilots who transition to single pilot, IFR, multi-engine environments without any prior experience typified by most flight instructors aspiring for career positions with airlines and corporate flight departments. To the best of the researchers' knowledge, there have been no formal studies undertaken in this specific area of research and thus any significant review of scholarly literature cannot be reported at this time. Experts advise that a claim of no literature available for a topic may lead the reader to assume the topic is not worth studying, there may be no way to study it, or the search is too narrow. At a minimum, studies tangentially related, should be presented so that full understanding of the situation can be comprehended (Merriam, 1998). Consequently, the researchers relied on tangentially related studies and industry based information from trade journals on similar problematic areas including (but not limited to) low time pilot/owners transitioning into very light jets (VLJs) and entry level positions within regional airlines.

Clearly, a tangentially related problem involving VLJ development is the increased accessibility to affluent low time owner pilots. According to Crystal (2006), the influx of VLJs has been a cause for concern by insurance companies and the FAA about safety and training issues of single-pilot operations at higher speeds and altitudes. Crystal further elaborated that single-pilot jet operations often involve owner/pilots with minimal experience and 
insurance companies will either write policies with extremely high premiums or refuse to write policies altogether. Even VLJ manufacturers are concerned about pilot competencies. Fred George, a writer for Business \& Commercial Aviation, stated the following: "Based on skills assessment results, Eclipse may actually tell some low proficiency owner pilots that they can either name another pilot or accept a refund for their delivery positions" (George, 2007, p. 73).

Other tangentially related areas include the present day demand for regional airline pilots. "For regional airline employers in particular, the dilemma is to reduce inventory and cockpit seats or hire relatively inexperienced crewmembers based on some evaluation formula with questionable predictive validity" (Fanjoy, Young, \& Suckow, 2006, p. 71). This has become increasingly important in an environment where regional airline pilots are in high demand and corresponding experience levels are low.

\section{Participants}

\section{Methodology}

The participants for this study included 202 representatives (chief pilots and directors of flight operations) from aircraft charter companies who were members of NATA. A descriptive type survey questionnaire was developed by the author to solicit opinions and comments from representatives from the aircraft charter companies. Two key assumptions were made about the participants during the study: (a) The representatives from the charter companies had reasonable knowledge of their hiring practices and Federal Aviation Regulations (FARs) governing pilot training; and (b) the representatives responded to the questionnaire in a truthful and sincere manner using their professional and experiential expertise.

\section{Research Instrument}

The instrument used to collect the data was a survey questionnaire developed specifically for this study. The survey was distributed to 203 representatives via US mail. The survey was comprised of two sections. The first section utilized a series of questions that solicited the representatives' views concerning a typical new hire commercial pilot's previous flight experience. For example, survey questions addressed previous experience in high performance single and multi-engine aircraft, previous experience flying in IMC during the day and night, and flight experience over mountainous terrain. The survey questionnaire also queried the representatives about the effectiveness of responding to a notice of proposed rulemaking (NPRM). The first section of the survey used Likert scale designations Disagree, Somewhat Disagree, Somewhat Agree, Agree, Not Certain, and Not Apply for gathering data. A Likert scale indicates the extent of agreement or disagreement with a particular attitude, belief, or judgment (Tuckman, 1988). The second section of the survey instrument incorporated a demographic section. Responses left blank by the respondents were indicated by $N / R$ (No Report). In evaluating the data presented in the following tables, rounding errors should be taken into consideration.

\section{Demographics and Analysis \\ Data Analysis}

Data from the survey questionnaires were compiled from the software program, Statistical Package for Social Sciences (SPSS) (2003). The research data were analyzed by using a Pearson chi square test from Hinkle, Wiersma, and Jurs (1994). After performing a Pearson chi square test, it was found that some of the data results were extremely skewed or expected frequencies were less than five (SPSS Reference Guide, 1990). As a result, the cells were collapsed into a $2 \times 2$ contingency table and Fisher's Exact Test was used to examine the significance of the association between the two variables (Wikipedia, 2005). The most prominent demographic characteristics were gender. Of the usable 190 respondents reporting gender, $181(95.3 \%)$ were male which made any type of statistical inference between gender and respondent opinion responses on the Likert scale inconclusive.

\section{Cross Tabulations}

The data in Table 1 show cross tabulation results between the respondents' opinions and their age range. Collectively, 144 of the respondents $(72.7 \%)$ disagree/somewhat disagree that a typical new hire commercial pilot has an adequate amount of previous experience as PIC flying high performance multi-engine aircraft. The heaviest concentrations of respondents who disagree/somewhat disagree were in the 41-50 age range. Conversely, only 31 of the respondents $(15.7 \%)$ agree that a new hire's previous multi-engine experience is adequate. Over one-half of the respondents $(n=110,55.6 \%)$ who disagree/somewhat disagree were in the 31-50 age range. 
Table 1

Comparison Between Flying High Performance Multi-Engine Aircraft and Respondents' Age Range

\begin{tabular}{|c|c|c|c|c|c|}
\hline \multirow[b]{2}{*}{ Statement } & \multicolumn{5}{|c|}{ Frequency $(N=198)$} \\
\hline & \multicolumn{5}{|c|}{ Age Range } \\
\hline \multicolumn{6}{|c|}{$\begin{array}{l}\text { A typical new hire commercial } \\
\text { pilot has an adequate amount of } \\
\text { previous experience as PIC in a } \\
\text { single pilot environment flying } \\
\text { high performance multi-engine } \\
\text { aircraft. }\end{array}$} \\
\hline Disagree & 13 & 24 & 43 & 0 & 80 \\
\hline Somewhat Disagree & 20 & 24 & 19 & 1 & 64 \\
\hline Somewhat Agree & 8 & 7 & 6 & 2 & 23 \\
\hline Agree & 7 & 15 & 9 & 0 & 31 \\
\hline Total & 48 & 70 & 77 & 3 & \\
\hline
\end{tabular}


The data compiled in Table 2 compare the respondents' opinions with their level of education. More than one-half of the respondents ( $n=127,55.9 \%$ ) have either a bachelor's or master's degree. Ofall the respondents who have a high school diploma/GED as their highest level of education to those who have a bachelor's degree, 141 (61.6\%) disagree/somewhat disagree that a typical new hire has adequate multi-engine experience and the numbers increase to 160 respondents $(69.9 \%)$ if the master's degree holder respondents are included. Some of the respondents $(n$ $=34,14.8 \%$ ) agree that a typical new hire candidate has an adequate amount of previous experience flying high performance multi-engine aircraft.

Table 2

Comparison Between Flying High Performance Multi-Engine Aircraft and Respondents' Highest Level of Education

Frequency $(N=229)$

\begin{tabular}{lccccc}
\cline { 2 - 4 } Statement & Less than & High School & Technical/Cert. Bachelor's & Master's & Other \\
& High School & Diploma/GED & Program & Degree & Degree
\end{tabular}

\begin{abstract}
A typical new hire
commercial pilot has

an adequate amount of

previous experience as

PIC in a single pilot

environment flying high

performance multi-engine

aircraft.
\end{abstract}

\begin{tabular}{lcccccc} 
Disagree & 0 & 13 & 13 & 42 & 13 & 4 \\
Somewhat Disagree & 0 & 23 & 19 & 31 & 6 & 5 \\
Somewhat Agree & 0 & 7 & 4 & 10 & 4 & 1 \\
Agree & 0 & 6 & 4 & 18 & 3 & 3 \\
\hline Total & 0 & 49 & 40 & 101 & 26 & 13 \\
\hline
\end{tabular}


Table 3 cross-tabulates the respondents' opinions with their time of employment (in years) at their current position with their opinion concerning the adequacy of previous PIC multi-engine experience. Of all the respondents, almost three-fourths $(n=142,71.8 \%)$ disagree/somewhat disagree that a new hire commercial pilot has previous adequate experience as PIC in multiengine aircraft which is consistent with the data presented in Table 1 comparing respondents' opinions with their age range. Table 3 also shows that 97 of the respondents (50.0\%) who disagree/somewhat disagree have six or more years of experience in their present position. The seasoned respondents with 16 or more years of experience in their present position accounted for one-quarter of all the respondents $(n=50,25.2 \%)$. Only 11 of the respondents (5.6\%) agree that a new hire's previous PIC experience in multi-engine aircraft is adequate.

Table 3

Comparison Between Flying High Performance Multi-Engine Aircraft and Respondents' Time of Employment at Present Position

\begin{tabular}{|c|c|c|c|c|c|}
\hline \multirow[b]{3}{*}{ Statement } & \multicolumn{5}{|c|}{ Frequency $(N=198)$} \\
\hline & \multicolumn{5}{|c|}{ Years Employed } \\
\hline & 5 or $<$ & $6-10$ & $11-15$ & 16 or $>$ & Total \\
\hline \multicolumn{6}{|c|}{$\begin{array}{l}\text { A typical new hire commercial } \\
\text { pilot has an adequate amount of } \\
\text { previous experience as PIC in a } \\
\text { single pilot environment flying } \\
\text { high performance multi-engine } \\
\text { aircraft. }\end{array}$} \\
\hline Disagree & 22 & 16 & 10 & 30 & 78 \\
\hline Somewhat Disagree & 23 & 16 & 5 & 20 & 64 \\
\hline Somewhat Agree & 9 & 4 & 4 & 5 & 22 \\
\hline Agree & 8 & 6 & 6 & 11 & 31 \\
\hline Total & 62 & 42 & 25 & 66 & \\
\hline
\end{tabular}


The data in Table 4 illustrate a comparison between the respondents' opinions and the highest FAA certificate held. Note the two highest cells are respondents who are ATP rated and disagree/somewhat disagree at $n=52$ (26.8\%) and $n=45(23.2 \%)$ respectively. Combined, ATP rated pilots account one-half of all the respondents $(n=97$, $50.0 \%$ ) who do not believe that a typical new hire commercial pilot has adequate previous PIC multi-engine experience compared to 40 respondents $(20.6 \%)$ who believe the previous experience is adequate. Of all the respondents, less than one-fifth $(n=30,15.5 \%)$ agree that the previous experience was adequate. Note that 22 respondents $(11.3 \%)$ somewhat agree which suggests that there is some degree of hesitation in their beliefs that previous new hire experience flying multi-engine aircraft is adequate.

Table 4

Comparison Between Flying High Performance Multi-Engine Aircraft and Respondents' Highest FAA Certificate Held

\begin{tabular}{|c|c|c|c|c|}
\hline \multirow[b]{2}{*}{ Statement } & \multicolumn{4}{|c|}{ Frequency $(N=194)$} \\
\hline & None & $\begin{array}{l}\text { FAA Certifica } \\
\text { Commercial }\end{array}$ & $\begin{array}{l}\text { te Held } \\
\text { ATP }\end{array}$ & Total \\
\hline \multicolumn{5}{|c|}{$\begin{array}{l}\text { A typical new hire commercial } \\
\text { pilot has an adequate amount of } \\
\text { previous experience as PIC in a } \\
\text { single pilot environment flying } \\
\text { high performance multi-engine } \\
\text { aircraft. }\end{array}$} \\
\hline Disagree & 1 & 26 & 52 & 79 \\
\hline Somewhat Disagree & 3 & 15 & 45 & 63 \\
\hline Somewhat Agree & 0 & 5 & 17 & 22 \\
\hline Agree & 1 & 6 & 23 & 30 \\
\hline Total & 5 & 52 & 137 & \\
\hline
\end{tabular}


In Table 5, a comparison between the respondents' opinions about a typical new hire's previous experience flying in IMC during the day and the respondents' age range shows those who disagree/somewhat disagree $(n=102$, $51.5 \%)$ is approximate to those respondents who somewhat agree/agree $(n=96,48.5 \%)$. The highest cells of respondents is those who are in the $31-40$ age range that somewhat disagree $(n=26,13.1 \%)$ and $41-50$ age range $(n$ $=28,14.1 \%$ ) respectively. The individuals who disagree/somewhat disagree and were in the $31-50$ combined age category accounted for less than one-half ( $n$ $=82,41.4 \%$ ) of all the respondents. Only 38 respondents (19.2\%) agree with the adequacy of new hire's previous experience flying in IMC during the day.

Table 5

Comparison Between Flying in IMC During the Day and Respondents' Age Range

\begin{tabular}{|c|c|c|c|c|c|}
\hline \multirow[b]{3}{*}{ Statement } & \multicolumn{5}{|c|}{ Frequency $(N=198)$} \\
\hline & \multicolumn{5}{|c|}{ Age Range } \\
\hline & 30 or less & $31-40$ & $41-50$ & 51 or more & Total \\
\hline \multicolumn{6}{|c|}{$\begin{array}{l}\text { A typical new hire commercial } \\
\text { pilot has an adequate amount of } \\
\text { previous experience as PIC in a } \\
\text { single pilot environment flying } \\
\text { in instrument meteorological } \\
\text { conditions (IMC) during the } \\
\text { day. }\end{array}$} \\
\hline Disagree & 3 & 12 & 16 & 0 & 31 \\
\hline Somewhat Disagree & 17 & 26 & 28 & 0 & 71 \\
\hline Somewhat Agree & 19 & 18 & 18 & 3 & 58 \\
\hline Agree & 9 & 14 & 15 & 0 & 38 \\
\hline Total & 48 & 70 & 77 & 3 & \\
\hline
\end{tabular}


The data in Table 6 show cross tabulation results between the respondents' opinions and their highest level of education with respect to a typical new hire's previous experience flying in IMC during the day. Of all the respondents, $127(58.8 \%)$ were college educated having obtained a bachelor's or a master's degree as the highest degree obtained. With respect to all the various levels of education, 114 respondents (49.8\%) disagree/somewhat disagree compared to $115(50.2 \%)$ who agree/somewhat agree. Seventy-two respondents (31.4\%) somewhat agree that a new hire pilot's previous experience is adequate which suggests that these respondents have some level of uncertainty.

Table 6

Comparison Between Flying in Daytime IMC and Respondents' Highest Level of Education

Frequency $(N=229)$

Education

Statement

Less than High School Technical/Cert. Bachelor's

Master's Other High School Diploma/GED

Program

Degree

Degree

\begin{abstract}
A typical new hire commercial pilot has an adequate amount of previous experience as PIC in a single pilot environment flying in instrument meteorological conditions (IMC) during the day.
\end{abstract}

\begin{tabular}{lcccccr} 
Disagree & 0 & 6 & 6 & 13 & 8 & 3 \\
Somewhat Disagree & 0 & 19 & 13 & 37 & 6 & 3 \\
Somewhat Agree & 0 & 16 & 16 & 31 & 6 & 3 \\
Agree & 0 & 8 & 5 & 20 & 6 & 4 \\
\hline otal & 0 & 49 & 40 & 101 & 26 & 13 \\
\hline
\end{tabular}


Table 7 cross-tabulates respondent opinions with the range of years employed. There were 100 respondents (51.3\%) who reported disagree/somewhat disagree with the adequacy of a new hire pilot's experience. Fifty-seven respondents (29.2\%) somewhat agree with the previous experience. In combining disagree/somewhat disagree responses with somewhat agree, there are 157 respondents $(80.5 \%)$ who fall into the range from disagree to somewhat agree suggesting there is some doubt that lies with a new hire's previous experience as being adequate in flying IMC during the day.

Table 7

Comparison Between Flying in Daytime IMC and Respondents' Time of Employment at Present Position

\begin{tabular}{|c|c|c|c|c|c|}
\hline \multirow[b]{3}{*}{ Statement } & \multicolumn{5}{|c|}{ Frequency $(N=195)$} \\
\hline & \multicolumn{5}{|c|}{ Years Employed } \\
\hline & 5 or $<$ & $6-10$ & $11-15$ & 16 or $>$ & Total \\
\hline \multicolumn{6}{|c|}{$\begin{array}{l}\text { A typical new hire commercial } \\
\text { pilot has an adequate amount of } \\
\text { previous experience as PIC in a } \\
\text { single pilot environment flying } \\
\text { in instrument meteorological } \\
\text { conditions (IMC) during } \\
\text { the day. }\end{array}$} \\
\hline Disagree & 10 & 4 & 6 & 10 & 30 \\
\hline Somewhat Disagree & 22 & 13 & 9 & 26 & 70 \\
\hline Somewhat Agree & 20 & 17 & 4 & 16 & 57 \\
\hline Agree & 10 & 8 & 6 & 14 & 38 \\
\hline Total & 62 & 42 & 25 & 66 & \\
\hline
\end{tabular}


In Table 8, a comparison is made between respondent opinions concerning previous experience flying IMC during the day and the highest FAA certificate held. Slightly over one-half of all the respondents $(n=101$, $52.1 \%$ ) disagree/somewhat disagree with the assumption that a typical new hire pilot has adequate PIC experience flying in IMC during the day. Only 31 respondents $(16.0 \%)$ disagree compared to $36(18.6 \%)$ who agree. The data in Table 8 seem to indicate that respondents' views regardless of certificate type (assuming they had a commercial or ATP certificate) were somewhat uniform.

\section{Table 8}

Comparison Between Flying in Daytime IMC and Respondents' Highest FAA Certificate Held

\begin{tabular}{lll}
\hline & \multicolumn{3}{c}{ Frequency $(N=194)$} \\
\cline { 2 - 3 } Statement & None & $\begin{array}{l}\text { FAA Certificate Held } \\
\text { Commercial ATP Total }\end{array}$ \\
\hline
\end{tabular}

A typical new hire commercial pilot has an adequate amount of previous experience as PIC in a single pilot environment flying in instrument meteorological conditions (IMC) during the day.

\begin{tabular}{lrrrr} 
Disagree & 0 & 9 & 22 & 31 \\
Somewhat Disagree & 2 & 21 & 47 & 70 \\
Somewhat Agree & 2 & 14 & 41 & 57 \\
Agree & 1 & 8 & 27 & 36 \\
& & & & \\
\hline
\end{tabular}


Table 9 shows cross tabulation results between the respondents' opinions regarding adequate previous experience as PIC experience in IMC at night. Sixty-nine respondents (34.8\%) disagree, and 61 somewhat disagree (30.8\%) resulting in two-thirds of the respondents $(n=130$, $65.7 \%$ ) who disagree/somewhat disagree with experience adequacy. Compared to Table 5 which cross-tabulated the opinions to PIC experience in IMC during the day, 102 respondents disagree/somewhat disagree $(n=102,51.5 \%)$ suggesting that a greater number of respondents believe that a typical new hire pilot's previous experience in IMC at night is inadequate compared to IMC day flying.

Table 9

Comparison Between Flying in IMC at Night and Respondents' Age Range

\begin{tabular}{|c|c|c|c|c|c|c|}
\hline \multirow[b]{3}{*}{ Statement } & \multicolumn{5}{|c|}{ Frequency $(N=198)$} & \multirow[b]{3}{*}{ Tota } \\
\hline & \multicolumn{5}{|c|}{ Age Range } & \\
\hline & 30 or less & $31-40$ & $41-50$ & 51 or more & $\mathbf{N} / \mathbf{R}$ & \\
\hline \multicolumn{7}{|c|}{$\begin{array}{l}\text { A typical new hire commercial } \\
\text { pilot has an adequate amount of } \\
\text { previous experience as PIC in a } \\
\text { single pilot environment flying } \\
\text { in instrument meteorological } \\
\text { conditions (IMC) at night. }\end{array}$} \\
\hline Disagree & 13 & $\mathbf{0}$ & 26 & 30 & 0 & 69 \\
\hline Somewhat Disagree & 14 & 0 & 20 & 27 & 0 & 61 \\
\hline Somewhat Agree & 15 & 0 & 12 & 11 & 2 & 40 \\
\hline Agree & 6 & 0 & 12 & 9 & 1 & 28 \\
\hline Total & 48 & 0 & 70 & 77 & 3 & \\
\hline
\end{tabular}


The data in Table 10 show cross tabulation results between the respondents' opinions concerning a new hire's adequate amount of experience in IMC at night and their highest level of education. One-third of the respondents ( $n$ $=77,33.0 \%$ ) disagree and another one-third somewhat disagree resulting in two-thirds $(n=154,66.0 \%)$ who fall into the disagree/somewhat disagree range. If the somewhat agree responses are included, 199 respondents (85.4\%) express some kind of concern over the adequacy of previous experience. Forty-five respondents (19.3\%) somewhat agree and $34(14.6 \%)$ agree resulting in 79 individuals (33.9\%) who are classified in the somewhat agree/agree range.

Table 10

Comparison Between Flying in IMC at Night and Respondents' Highest Level of Education

Frequency $(N=233)$

Statement

Less than High School Technical/Cert. Bachelor's Master's Other

High School Diploma/GED Program Degree Degree

A typical new hire commercial pilot has an adequate amount of previous experience as PIC in a single pilot environment flying in instrument meteorological conditions (IMC) at night.

\begin{tabular}{lcccccc} 
Disagree & 0 & 13 & 11 & 35 & 12 & 6 \\
Somewhat Disagree & 0 & 22 & 17 & 30 & 6 & 2 \\
Somewhat Agree & 0 & 9 & 10 & 18 & 6 & 2 \\
Agree & 0 & 5 & 2 & 18 & 6 & 3 \\
\hline Total & 0 & 49 & 40 & 101 & 30 & 13 \\
\hline
\end{tabular}


In Table 11, a comparison between respondent opinions about the adequacy of a new hire's previous experience in IMC at night and years employed indicates that 67 respondents (34.4\%) disagree compared to 61 (31.3\%) who somewhat disagree. This accounts for twothirds of all the individuals $(n=128,65.7 \%)$ who express concern for the adequacy of previous experience. The cell with the largest number is the respondents who have 5 or less years $(n=28,14.3 \%)$ followed by those with 16 or more years of experience in their current position $(n=26$, $13.3 \%)$. The two largest timeframes of employment are the 5 years or less $(n=62,31.8 \%)$ followed by 16 years or more $(n=66,33.8 \%)$.

Table 11

Comparison Between Flying in IMC at Night and Respondents' Time of Employment at Present Position

\begin{tabular}{lccccc}
\hline & \multicolumn{5}{c}{ Frequency $(N=195)$} \\
\cline { 2 - 6 } Statement & 5 or $<$ & $6-10$ & $11-15$ & 16 or $>$ & Total \\
\hline $\begin{array}{l}\text { A typical new hire commercial } \\
\text { pilot has an adequate amount of } \\
\text { previous experience as PIC in a }\end{array}$ & & & & & \\
$\begin{array}{l}\text { single pilot environment flying } \\
\text { in instrument meteorological } \\
\text { conditions (IMC) at night. }\end{array}$ & & & & & \\
$\quad$ Disagree & 28 & 11 & 9 & 19 & 67 \\
$\quad$ Somewhat Disagree & 14 & 14 & 7 & 26 & 61 \\
$\quad$ Somewhat Agree & 14 & 10 & 4 & 12 & 40 \\
$\quad$ Agree & 6 & 7 & 5 & 9 & 27 \\
\hline Total & 62 & 42 & 25 & 66 & \\
\hline
\end{tabular}


Table 12 illustrates a comparison between the respondents' opinions concerning a new hire's previous experience in IMC at night and the highest FAA certificate held. Like Table 11, Table 12 is also somewhat consistent at it shows 68 respondents (35.0\%) disagree and 61 (31.4\%) somewhat disagree which accounts for two-thirds of all the respondents $(n=129,66.4 \%)$. Only 39 respondents $(20.1 \%)$ somewhat agree compared to only $26(13.4 \%)$ who agree. The largest value was 45 ATP rated respondents (23.2\%) who disagree followed by 44 ATP rated respondents (22.7\%) who somewhat disagree. Only 26 (13.4\%) believe that a typical new hire commercial pilot has an adequate amount of previous experience as PIC in IMC at night.

Table 12

Comparison Between Flying in IMC at Night and Respondents' Highest FAA Certificate Held

\begin{tabular}{|c|c|c|c|c|}
\hline \multirow[b]{3}{*}{ Statement } & \multicolumn{4}{|c|}{ Frequency $(N=194)$} \\
\hline & \multicolumn{4}{|c|}{ FAA Certificate Held } \\
\hline & None & Commercial & ATP & Total \\
\hline \multicolumn{5}{|c|}{$\begin{array}{l}\text { A typical new hire commercial } \\
\text { pilot has an adequate amount of } \\
\text { previous experience as PIC in a } \\
\text { single pilot environment flying } \\
\text { in instrument meteorological } \\
\text { conditions (IMC) at night. }\end{array}$} \\
\hline Disagree & 0 & 23 & 45 & 68 \\
\hline Somewhat Disagree & 2 & 15 & 44 & 61 \\
\hline Somewhat Agree & 2 & 10 & 27 & 39 \\
\hline Agree & 1 & 4 & 21 & 26 \\
\hline Total & 5 & 52 & 137 & \\
\hline
\end{tabular}


In Table 13, an illustration is made that compares respondent opinions concerning a new hire commercial pilot's previous experience as PIC flying over mountainous terrain with the age range of the respondents. Notably, there are 79 respondents $(41.4 \%)$ disagree with the previous statement. An additional 58 respondents (30.4\%) somewhat disagree which increases the number of respondents who disagree/somewhat disagree to 137 (71.7\%). Altogether, 169 respondents $(\mathbf{8 8 . 5 \% )}$ disagree, somewhat disagree, or somewhat agree. Only 22 respondents $(11.5 \%)$ agree that previous mountainous experience by new hire pilots was adequate.

\section{Table 13}

Comparison Between Flying over Mountainous Terrain and Respondents' Age Range

\begin{tabular}{lcccccc}
\hline & \multicolumn{5}{c}{ Frequency $(N=191)$} \\
\cline { 2 - 6 } Statement & 30 or less & $31-40$ & $\begin{array}{c}\text { Age Range } \\
41-50\end{array}$ & 51 or more & N/R & Total \\
\hline $\begin{array}{l}\text { A typical new hire commercial } \\
\text { pilot has an adequate amount of } \\
\text { previous experience as PIC in a } \\
\text { single pilot environment flying } \\
\text { over mountainous terrain. }\end{array}$ & & & & & \\
$\quad \begin{array}{l}\text { Disagree } \\
\text { Somewhat Disagree }\end{array}$ & 17 & 0 & 25 & 37 & 0 & 79 \\
$\quad$ Somewhat Agree & 17 & 0 & 21 & 19 & 1 & 58 \\
$\quad$ Agree & 8 & 0 & 11 & 12 & 1 & 32 \\
\hline Total & 5 & 0 & 9 & 7 & 1 & 22 \\
\hline
\end{tabular}


The data in Table 14 show cross tabulation results between the respondents' opinions concerning a new hire commercial pilot's previous experience as PIC flying over mountainous terrain and the highest level of education for the respondents. Almost three-fourths of the respondents ( $n$ $=163,73.4 \%$ ) disagree/somewhat disagree that a typical new hire commercial pilot has previous adequate experience flying over mountainous terrain. Thirty-five respondents $(15.8 \%)$ somewhat agree while only $24(10.8 \%)$ agree. Over one-half $(n=123,55.4 \%)$ of the respondents have either a bachelor's or a master's degree.

Table 14

Comparison Between Flying over Mountainous Terrain and Respondents' Highest Level of Education

\begin{tabular}{|c|c|c|c|c|c|c|}
\hline \multirow[b]{2}{*}{ Statement } & \multicolumn{6}{|c|}{ Frequency $(N=222)$} \\
\hline & $\begin{array}{l}\text { Less than } \\
\text { High School }\end{array}$ & $\begin{array}{c}\text { High School } \\
\text { Diploma/GED }\end{array}$ & $\begin{array}{l}\text { Education } \\
\text { Technical/Cert. } \\
\text { Program }\end{array}$ & $\begin{array}{c}\text { Bachelor's } \\
\text { Degree }\end{array}$ & $\begin{array}{l}\text { Master's } \\
\text { Degree }\end{array}$ & Other \\
\hline \multicolumn{7}{|l|}{$\begin{array}{l}\text { A typical new hire } \\
\text { commercial pilot has } \\
\text { an adequate amount of } \\
\text { previous experience as } \\
\text { PIC in a single pilot } \\
\text { environment flying over } \\
\text { mountainous terrain. }\end{array}$} \\
\hline Disagree & 0 & 22 & 14 & 41 & 11 & 3 \\
\hline Somewhat Disagree & $\mathbf{0}$ & 17 & 16 & 28 & 6 & 5 \\
\hline Somewhat Agree & 0 & 7 & 6 & 18 & 2 & 2 \\
\hline Agree & 0 & 3 & 1 & 12 & 5 & 3 \\
\hline Total & 0 & 49 & 37 & 99 & 24 & 13 \\
\hline
\end{tabular}




\section{Implications of Current Federal}

In Table 15, cross tabulation results between the respondents' opinions concerning a new hire commercial pilot's previous PIC experience over mountainous terrain and the years of employment range is shown. Approximately two-fifths of the respondents $(n=77,41.0 \%)$ disagree and $58(30.9 \%)$ somewhat disagree. This equates to 135 respondents $(71.8 \%)$ who clearly have reservations about the adequacy of previous mountainous flight time. Additionally, 32 respondents (17.0\%) somewhat agree which may suggest that 167 respondents $(88.8 \%)$ have reservations about the adequacy of previous mountainous experience. Only 21 individuals (11.2\%) agree that previous new hire mountainous experience is adequate.

\section{Table 15}

Comparison Between Flying over Mountainous Terrain and Respondents 'Time of Employment at Present Position

\begin{tabular}{lccccc}
\hline & \multicolumn{5}{c}{ Frequency $(N=188)$} \\
\cline { 2 - 6 } & 5 or $<$ & $6-10$ & $11-15$ & 16 or $>$ & Total \\
Statement & & & & & \\
\hline $\begin{array}{l}\text { A typical new hire commercial } \\
\text { pilot has an adequate amount of } \\
\text { previous experience as PIC in a } \\
\text { single pilot environment flying } \\
\text { over mountainous terrain. }\end{array}$ & & & & & \\
$\quad$ Disagree & 30 & 10 & 12 & 25 & 77 \\
$\quad$ Somewhat Disagree & 15 & 18 & 5 & 20 & 58 \\
$\quad$ Somewhat Agree & 7 & 10 & 3 & 12 & 32 \\
$\quad$ Agree & 6 & 4 & 4 & 7 & 21 \\
\hline Total & 58 & 42 & 24 & 64 & \\
\hline
\end{tabular}


Table 16 shows cross tabulation results between the respondents' opinions concerning a new hire commercial pilot's previous PIC experience over mountainous terrain and the highest FAA certificate held. Similar to the disagree/somewhat disagree results from Table 15, Table 16 also shows that approximately two-fifths of the respondents $(n=78,41.7 \%)$ disagree and $58(31.0 \%)$ somewhat disagree resulting in a vast majority of the respondents ( $n=136$, $72.7 \%$ ) who express reservations about the adequacy of previous mountainous experience. Only one commercially rated respondent $(0.5 \%)$ agrees that previous mountainous experience is adequate compared to $18 \mathrm{ATP}$ rated respondents $(9.6 \%)$ who also share the same opinion.

Table 16

Comparison Between Flying over Mountainous Terrain and Respondents' Highest FAA Certificate Held

\begin{tabular}{|c|c|c|c|c|}
\hline \multirow[b]{3}{*}{ Statement } & \multicolumn{4}{|c|}{ Frequency $(N=187)$} \\
\hline & \multicolumn{4}{|c|}{ FAA Certificate Held } \\
\hline & None & Commercial & ATP & Total \\
\hline \multicolumn{5}{|c|}{$\begin{array}{l}\text { A typical new hire commercial } \\
\text { pilot has an adequate amount of } \\
\text { previous experience as PIC in a } \\
\text { single pilot environment flying } \\
\text { over mountainous terrain. }\end{array}$} \\
\hline Disagree & 0 & 22 & 56 & 78 \\
\hline Somewhat Disagree & 3 & 18 & 37 & 58 \\
\hline Somewhat Agree & 1 & 10 & 20 & 31 \\
\hline Agree & 1 & 1 & 18 & 20 \\
\hline Total & 5 & 51 & 131 & \\
\hline
\end{tabular}


The data in Table 17 show cross tabulation results between the respondents' opinions that a typical new hire commercial pilot has an adequate amount of previous experience as PIC in a single pilot environment flying in hazardous conditions (e.g., icing, slippery runways) and the respondents' age range. Nearly one-half of the respondents $(n=93,47.0 \%)$ disagree and an additional $59(29.8 \%)$ somewhat disagree which accounts for over three-fourths of the respondents $(n=152,76.8 \%)$ who disagree/somewhat disagree which could suggest that a similar number respondents who have reservations about previous mountainous experience (review Table 16) also have reservations about previous experience flying in hazardous conditions as illustrated in Table 17.

Table 17

Comparison Between Flying in Hazardous Conditions (Icing Conditions, Slippery Runways, etc.) and Respondents' Age Range

\begin{tabular}{|c|c|c|c|c|c|c|}
\hline \multirow[b]{3}{*}{ Statement } & \multicolumn{5}{|c|}{ Frequency $(N=198)$} & \multirow[b]{3}{*}{ Tota } \\
\hline & \multirow[b]{2}{*}{30 or less } & \multicolumn{3}{|c|}{ Age Range } & \multirow[b]{2}{*}{$N / R$} & \\
\hline & & $31-40$ & $41-50$ & 51 or more & & \\
\hline \multicolumn{7}{|c|}{$\begin{array}{l}\text { A typical new hire commercial } \\
\text { pilot has an adequate amount of } \\
\text { previous experience as PIC in a } \\
\text { single pilot environment flying } \\
\text { in hazardous conditions (icing } \\
\text { conditions, slippery runways, etc.) }\end{array}$} \\
\hline Disagree & 20 & 0 & 31 & 42 & 0 & 93 \\
\hline Somewhat Disagree & 16 & 0 & 22 & 21 & 0 & 59 \\
\hline Somewhat Agree & 10 & 0 & 9 & 7 & 3 & 29 \\
\hline Agree & 2 & $\mathbf{0}$ & 7 & 8 & 0 & 17 \\
\hline Total & 48 & $\mathbf{0}$ & 69 & 78 & 3 & \\
\hline
\end{tabular}


The data in Table 18 show the results between the respondents' opinions that a typical new hire commercial pilot has an adequate amount of previous experience as PIC in a single pilot environment flying in hazardous conditions (e.g., icing, slippery runways) and the respondents' highest level of education. Similar to Table 14 that compares mountainous experience to highest level of education, Table
18 also shows a numerical consistency in the respondents' opinions. Of the respondents, nearly one-half $(n \doteq 109$, $47.6 \%$ ) disagree with the adequacy of previous hazardous conditions experience while 70 (30.6\%) somewhat disagree. This accounts for 179 respondents (78.2\%) who have concerns that previous experience flying in hazardous conditions is adequate.

Table 18

Comparison Between Flying in Hazardous Conditions (Icing Conditions, Slippery Rumways, etc.) and Respondents' Highest Level of Education

Frequency $(N=229)$

Education

Statement

Less than High School Technical/Cert. Bachelor's

Master's

Other High School Diploma/GED

Program

Degree

Degree

\begin{abstract}
A typical new hire commercial pilot has an adequate amount of previous experience as PIC in a single pilot environment flying in hazardous conditions (icing conditions, slippery runways, etc.)
\end{abstract}

\begin{tabular}{lcccccc} 
Disagree & 0 & 22 & 19 & 49 & 13 & 6 \\
Somewhat Disagree & 0 & 17 & 15 & 29 & 5 & 4 \\
Somewhat Agree & 0 & 6 & 4 & 13 & 6 & 1 \\
Agree & 0 & 4 & 2 & 10 & 2 & 2 \\
\hline total & 0 & 49 & 40 & 101 & 26 & 13 \\
\hline
\end{tabular}


The data in Table 19 show cross tabulation results between the respondents' opinions that a typical new hire commercial pilot has an adequate amount of previous experience as PIC in a single pilot environment flying in hazardous conditions (e.g., icing, slippery runways) and the respondents' time of employment at their present position.
Of the respondents, 91 (46.7\%) disagree compared to almost one-third $(n=59,30.3 \%)$ who somewhat disagree resulting in over three-fourths $(n=150,76.9 \%)$ who can be categorized as disagree/somewhat disagree with the adequacy of previous hazardous experience.

Table 19

Comparison Between Flying in Hazardous Conditions (Icing Conditions, Slippery Runways, etc.) and Respondents' Time of Employment at Present Position

\begin{tabular}{|c|c|c|c|c|c|}
\hline \multirow[b]{3}{*}{ Statement } & \multicolumn{5}{|c|}{ Frequency $(N=195)$} \\
\hline & \multicolumn{5}{|c|}{ Years Employed } \\
\hline & 5 or $<$ & $6-10$ & $11-15$ & 16 or $>$ & Total \\
\hline \multicolumn{6}{|c|}{$\begin{array}{l}\text { A typical new hire commercial } \\
\text { pilot has an adequate amount of } \\
\text { previous experience as PIC in a } \\
\text { single pilot environment flying } \\
\text { in hazardous conditions (icing } \\
\text { conditions, slippery runways, etc.) }\end{array}$} \\
\hline Disagree & 31 & 19 & 11 & 30 & 91 \\
\hline Somewhat Disagree & 20 & 12 & 5 & 22 & 59 \\
\hline Somewhat Agree & 7 & 10 & 5 & 6 & 28 \\
\hline Agree & 3 & 2 & 4 & 8 & 17 \\
\hline Total & 61 & 43 & 25 & 66 & \\
\hline
\end{tabular}


In Table 20, a contrast is made between the respondents' opinions that a typical new hire commercial pilot has an adequate amount of previous experience as PIC in a single pilot environment flying in hazardous conditions (e.g., icing, slippery runways) and the respondents' highest FAA certificate held. The results from Table 20 are consistent with the results that illustrate respondent opinions and years of employment from Table 19. Almost one-half of the ATP rated respondents $(n=91,46.9 \%)$ disagree that previous new hire commercial pilot experience is adequate. Fifty-nine more $(30.4 \%)$ somewhat disagree bringing the total number of disagree/somewhat disagree responses to $150(77.3 \%)$. Only 16 respondents (8.2\%) agree that previous hazardous flight experience is adequate.

Table 20

Comparison Between Flying in Hazardous Conditions (Icing Conditions, Slippery Runways, etc.) and Respondents' Highest FAA Certificate Held

\begin{tabular}{lcccc}
\hline & \multicolumn{4}{c}{ Frequency $(N=194)$} \\
\cline { 2 - 5 } Statement & None & FAA Certificate Held \\
Commercial & ATP & Total \\
\hline $\begin{array}{l}\text { A typical new hire commercial } \\
\text { pilot has an adequate amount of } \\
\text { previous experience as PIC in a } \\
\text { single pilot environment flying } \\
\text { in hazardous conditions (icing } \\
\text { conditions, slippery runways, etc.) }\end{array}$ & & & & \\
$\quad$ Disagree & 1 & 27 & 63 & 91 \\
$\quad$ Somewhat Disagree & 2 & 16 & 41 & 59 \\
$\quad$ Somewhat Agree & 1 & 8 & 19 & 28 \\
$\quad$ Agree & 1 & 1 & 14 & 16 \\
\hline Total & & & & \\
\hline
\end{tabular}




\section{Significant Relationships}

In Table 21, the results of a Pearson chi square test show that a significant relationship exists $(p<.05)$ between the respondents' time of employment at their current position and the level of agreement/disagreement with the belief that responding to an NPRM is effective. Many of the respondents $(n=99,59.6 \%)$ agree/somewhat agree that responding to an NPRM is an effective way to change FAA policy while 67 respondents $(40.3 \%)$ disagree/somewhat disagree. Twenty-eight individuals (16.9\%) who somewhat agree have been employed 16 or more years at their present position compared to only 3 individuals (1.8\%) employed for 11-15 years who disagree.

Table 21

Frequencies and Pearson Chi-Square Comparison of Responses to Responding to a NPRM and the Respondents' Time of Employment at Their Current Position

\begin{tabular}{|c|c|c|c|c|c|c|}
\hline \multirow[b]{3}{*}{ Statement } & \multicolumn{5}{|c|}{ Frequency $(N=166)$} & \multirow{3}{*}{$\begin{array}{c}p \text {-value for } \\
\text { Pearson Chi-Square }\end{array}$} \\
\hline & \multicolumn{5}{|c|}{ Years Employed } & \\
\hline & 5 or $<$ & $6-10$ & $11-15$ & 16 or $>$ & Total & \\
\hline \multicolumn{7}{|c|}{$\begin{array}{l}\text { Responding to a notice of } \\
\text { proposed rule making (NPRM) } \\
\text { is an effective way to change } \\
\text { FAA policy. }\end{array}$} \\
\hline Disagree & 11 & 6 & 3 & 8 & 28 & \\
\hline Somewhat Disagree & 13 & 13 & 4 & 9 & 39 & \\
\hline Somewhat Agree & 11 & 10 & 12 & 28 & 61 & \\
\hline Agree & 17 & 7 & 4 & 10 & 38 & \\
\hline Total & 52 & 36 & 23 & 55 & & $.050^{*}$ \\
\hline
\end{tabular}


In Table 22, the results of a Pearson chi square test show that a significant relationship exists between the respondents' time of employment at their current position and the level of agreement/disagreement with the respondents having responded to an NPRM. Of all the respondents, $135(70.7 \%)$ have responded to an NPRM compared to $56(29.3 \%)$ who never responded. Slightly more than one-quarter of all the individuals $(n=53,27.7 \%)$ who responded to an NPRM have been employed 16 or more years compared to only $3(1.6 \%)$ who are employed 11-15 years did not respond to an NPRM.

Table 22

Frequencies and Pearson Chi-Square Comparison of Responses to Responding to a NPRM and the Respondents' Time of Employment at Their Current Position

\begin{tabular}{|c|c|c|c|c|c|c|}
\hline \multirow[b]{3}{*}{ Statement } & \multicolumn{5}{|c|}{ Frequency $(N=191)$} & \multirow{3}{*}{$\begin{array}{c}p \text {-value for } \\
\text { Pearson Chi-Square }\end{array}$} \\
\hline & \multicolumn{5}{|c|}{ Years Employed } & \\
\hline & 5 or $<$ & $6-10$ & $11-15$ & 16 or $>$ & Total & \\
\hline \multicolumn{7}{|c|}{$\begin{array}{l}\text { Have you ever responded to } \\
\text { an NPRM? }\end{array}$} \\
\hline Yes & 32 & 28 & 22 & 53 & 135 & \\
\hline No & 27 & 15 & 3 & 11 & 56 & \\
\hline Total & 59 & 43 & 25 & 64 & & $.001^{* *}$ \\
\hline
\end{tabular}


The data in Table 23 show that a significant relationship exists between the respondents' opinions that a typical new hire commercial pilot has adequate previous PIC experience flying complex, single-engine aircraft and the respondents' age range. A Pearson chi square test was initially used although it revealed many cells with expected frequencies of less than five (SPSS Reference Guide, 1990). The cells were collapsed into a 2 × 2 contingency table combining disagree/somewhat disagree responses together and in a second cell, somewhat agree/agree opinions were also combined (see Table 23). In addition, the age ranges were reduced into two categories: 40 or less and 41 or more. Fisher's Exact Test was used to examine the significance of the association between the dependent and independent variables. Notably, only 12 individuals $(6.4 \%)$ who are 40 years of age or less disagree/somewhat disagree with the adequacy of a new hire pilot's previous experience flying complex high performance single engine aircraft compared to 66 individuals $(35.1 \%)$ age 41 or older somewhat agree/agree with the adequacy of previous experience.

Table 23

Frequencies and Fisher's Exact Test Comparison of Responses to Flying Complex High Performance Single-Engine Aircraft and Respondents' Age Range

\begin{tabular}{lcccc}
\hline & \multicolumn{3}{c}{ Frequency $(N=188)$} & \\
\cline { 2 - 3 } Statement & 40 or less & $\begin{array}{c}\text { Age Range } \\
41 \text { or more }\end{array}$ & Total & $\begin{array}{c}p \text {-value for } \\
\text { Fisher's Exact Test }\end{array}$ \\
\hline
\end{tabular}

A typical new hire commercial pilot has an adequate amount of previous experience as PIC in a single pilot environment flying complex high performance singleengine aircraft.

$\begin{array}{llll}\text { Disagree/Somewhat Disagree } & 12 & 77 & 89\end{array}$

$\begin{array}{llll}\text { Somewhat Agree/Agree } & 33 & 66 & 99\end{array}$

\begin{tabular}{llll}
\hline Total & 45 & 143 & $.002^{* *}$
\end{tabular}

${ }^{*} p<.05$, two-tailed. ${ }^{* *} p<.01$, two-tailed. 
The data in Table 24 show that a significant relationship exists between the respondents' level of agreement/disagreement in previous PIC experience flying VFR at night and the respondents' age range. There are 131 individuals (67.5\%) who somewhat agree/agree with the adequacy of a new hire's previous experience flying VFR at night compared to only $63(32.5 \%)$ who disagree/somewhat disagree. Of significance, almost one-half of the respondents $(n=91,46.9 \%)$ who are 41 or older somewhat agree/agree with the adequacy of previous experience while only seven individuals $(3.6 \%)$ in the $\mathbf{4 0}$ or less age range actually disagree/somewhat disagree.

Table 24

Frequencies and Fisher's Exact Test Comparison of Responses to Flying Under VFR at Night and Respondents' Age Range

\begin{tabular}{lcccc}
\hline & \multicolumn{3}{c}{ Frequency $(N=194)$} & \\
\cline { 2 - 3 } & 40 or less & $\begin{array}{c}\text { Age Range } \\
41 \text { or more }\end{array}$ & Total & $\begin{array}{c}p \text {-value for } \\
\text { Statement }\end{array}$ \\
\hline $\begin{array}{l}\text { A typical new hire commercial } \\
\text { pilot has an adequate amount of } \\
\text { previous experience as PIC in a } \\
\text { single pilot environment flying } \\
\text { under visual flight rules (VFR) } \\
\text { at night. }\end{array}$ & & & \\
\multicolumn{1}{c}{$\begin{array}{l}\text { Disagree/Somewhat Disagree } \\
\text { Somewhat Agree/Agree }\end{array}$} & 7 & 56 & 63 \\
\hline Total & 40 & 91 & 131 & \\
\hline
\end{tabular}

${ }^{*} p<.05$, two-tailed. ${ }^{* *} p<.01$, two-tailed.

\section{Conclusions}

This paper attempted to address the fundamental question: Is there a need to change FAA policy governing commercial pilot training and experience for low time pilots transitioning to single pilot/IFR environments? The results of this study reflect the professional opinions from experienced aviation professionals from NATA. Undoubtedly, the researchers found a two-fold weakness in this study: defining a universally accepted standard of adequate amount of previous experience and a lack of literature directly related to the study itself. Conversely, it should be noted the data also yielded useful information summarizing the opinions of aviation professionals who evaluate new hire commercial pilots.
Slightly more than one-half of the respondents ( $n=102,52 \%$ ) believe that a typical new hire commercial pilot does not have an adequate amount of previous experience as PIC in a single pilot environment flying in IMC day conditions and for night IMC conditions, the number of respondents increased $(n=130,66 \%)$. Also noteworthy was the finding that almost three-fourths of the respondents $(n=137,71 \%)$ believe that new hire commercial pilots do not have adequate experience in flying over mountainous terrain while 144 respondents $(73 \%)$ believe that new hire previous experience in flying high performance multi-engine aircraft was inadequate. Due to the fact that a majority of the respondents operate out of non-mountainous airports, it should be noted that the 
researchers have determined that previous experience flying over mountainous terrain may not be as relevant as flying during day or night IMC, etc. Over three-fourths of the respondents $(n=150,76.9 \%)$ argue that flying in hazardous conditions (icing conditions, slippery runways, etc.) is inadequate.

\section{Recommendations}

The results of this study have suggested that a typical new hire pilot is not adequately prepared for entry level positions in a single pilot/IFR environment commonly associated with aircraft charter companies. Based on the responses from NATA members, the researchers believe a significant need exists to change FAA policy governing commercial pilot training and experience for low time pilots transitioning to single pilot/IFR environments. Seemly, the FAA's regulatory policy in governing low time commercial pilots is antiquated although recent progress has been made. A study conducted by Middle Tennessee State University (MTSU) researchers Dornan, Craig, Gossett and Beckman (2006) found that the FAA Industry Training Standards (FITS) program is not only more efficient but "more effective in preparing students to make real-life decisions in the flight environment" (p. 58).

Based on these finding as well as the entire study, it is recommended that the FAA and charter companies work together to develop policies to require new hire commercial pilots (without any prior charter experience) to complete a "captain apprenticeship" or similar program by the charter operator as appropriate. For example, a charter operator in Buffalo, New York utilizing single pilot operated twin-engine aircraft (e.g., Beech Barons, Cessna 310s) should require new hire pilots to have prior experience flying in icing conditions and slippery runways before being released for line flying. This type of requirement would protect a commercial new hire pilot who has 2,000 hours total time and 500 hours multi-engine instructional time in a Beech Duchess who transitions to a charter operator for the first time. Obviously, this requirement would be exempt for a charter operator utilizing single pilot operated twinengine aircraft based in Honolulu. However, a charter operator located in Honolulu may need to implement an experience requirement before allowing a new hire commercial pilot to fly over the ocean to other islands at night. Requirements should depend on the location and geography of the charter operator, equipment used, and other environmental considerations without causing undue economic hardship.

Prior to implementation of these types of policies, it is recommended that the FAA conduct further research and coordinate their findings with the regional offices and charter company affiliates. The results of this study provide a compelling argument that the FAA needs to update the FARs for new hire commercial pilots. If there is any doubt that change needs to occur to the outdated FARs governing new hire commercial pilots, a recent accident review by Landsberg (2005) of the Aspen, CO accident in March 2001 that killed two experienced pilots and all 13 passengers in a Gulfstream III provides a haunting reality of what could soon happen again.t

Jeffrey A. Johnson is an associate professor in the Department of Aviation at St. Cloud State University. He has a BS in Aeronautical Studies from the University of North Dakota, a Master of Aeronautical Science from Embry-Riddle Aeronautical University (Daytona Beach), and a Ph.D. in Higher Education Administration from Bowling Green State University. He previously served as interim chair of the Department of Aviation at St. Cloud State University and is a member of NBAA and MBAA. He is a former regional airline pilot, mechanic and previously flew Beechjets as an ATP typed rated Captain for a fractional ownership company.

Steven L. Anderson is the department chair in the Department of Aviation at St. Cloud State University. He has a BS in Engineering Technology with an emphasis in Aviation and an MBA both from St. Cloud State University and a Ph.D. in Work, Community, and Family Education (Vocational Education) with an emphasis in Training and Development from the University of Minnesota. He is the Director of Flight Education and a designated pilot examiner.

Tara L. Harl is an assistant professor in the Department of Aviation at St. Cloud State University. She has an Ed.D. in Leadership Development from St. Mary's University of Minnesota, a M.Ed. in Aerospace Education from Middle Tennessee State University and a BS in Aviation Management from the University of Dubuque. She chairs the Professional Development Sub-Committee for the NBAA Corporate Aviation Management Committee and is a contributing member of the Minnesota Business Aviation Association (MBAA). She is an ATP type rated pilot with international experience. 


\section{References}

Acheson, D., \& Bowen, B. (1998). A 60-year retrospective analysis of primary flight education curricula: Implications for Today's Academy. In Flight Instructor Conference Proceedings: Elevating Our Profession (pp. 1-12). Daytona Beach, FL: Embry-Riddle Aeronautical University.

Campbell, R. (1987). Flight safety in general aviation. London: Collins Press.

Craig, P., Bertrand, J., Dornan, W., Gossett, S., \& Thorsby, K. (2005). Scenario-based private/instrument syllabus versus traditional maneuver-based syllabi: A Primary descriptive analysis. Collegiate Aviation Review, 23(1), 17-23.

Crystal, R. (2006, December). So you wanna fly a jet? Twin \& Turbine, 10(12), 31-37.

Dornan, W., Craig, P., Gossett, S., \& Beckman, W. (2006). Best evidence for the FAA industry training standards (FITS) program for pilot training in technically advanced aircraft. Collegiate Aviation Review, 24(1), 58-66.

Fanjoy, R., Young, J., \& Suckow, M. (2006). The experience factor: A regional airline view of pilot candidate qualifications, 24(1), 67-72.

George, F. (2007, June). The virtual copilot and the VLJ. Business \& Commercial Aviation, 68-74.

Gill, G. (2004). Perception of safety, safety violation and improvement of safety in aviation: Findings of a pilot study. Journal of Air Transportation, 9(3), 43-55.

Hinkle, D., Wiersma, W., \& Jurs, S. (1994). Applied statistics for the behavioral sciences (3rd ed.). Boston: Houghton Mifflin Company.

Hood, R. (2005, May). A matter of trust: Do you demonstrate good judgment? AOPA Flight Training, 79-80.

Jacobson, C., \& Mosier, K. (2005). Coherence and correspondence decision making in aviation: A study of pilot incident reports. International Journal of Applied Aviation Studies, 4(2), 123-134.

Landsberg, B. (2005, April). Safety pilot: Landmark accidents Aspen arrival. AOPA Pilot, 88-95.

Lutte, R., \& Bowen, B. (2000). The FAA: A tombstone agency? Putting the nickname to the test. Journal of Aviation/Aerospace Education \& Research, 18(1), 12-25.

Merriam, S. B. (1998). Qualitative research and case study applications in education. San Francisco, CA: Jossey-Bass.

Namowitz, D. (2005, May). Class dismissed. AOPA Flight Training, 51-53.

Regional Airline World. (2005). Florida feeds the regionals, 22(3), 8-12.

Schiff, B. (1987). The proficient pilot. New York: AOPA.

SPSS reference guide. (1990). Chicago: SPSS, Inc.

Statistical Package for Social Sciences (SPSS) (Version 12.0) [Computer Software]. (2003). Chicago: SPSS, Inc.

Tuckman, B. (1988). Conducting educational research. New York: Harcourt Brace Jovanovich.

Wikipedia (2005). Fisher's exact test. In Wikipedia: The free encyclopedia. Retrieved June 27, 2005, from http://en.wikipedia.org/wiki/Fisher's_exact_test 
